\title{
Side Effect of Lamotrigine in the Emergency Department; Stevens-Johnson Syndrome
}

\section{Acil Servise Lamotrijinin Yan Etkisi ile Başvuru; Stevens Johnson Sendromu}

Sinan Eliaçık ${ }^{1 \odot}$

\section{ABSTRACT}

Aim: Stevens Johnson Syndrome and Toxic Epidermal Necrolysis (SJS/TEN) is a life-threatening mucocutaneous skin reaction that usually develops against drugs, although there are various factors in its etiology. In this case report, SJS due to antiepileptic drug use will be briefly reviewed.

Case:20-year-old female patient was seen in the emergency department with a generalized tonic-clonic seizure. With the detailed anamnesis and laboratory findings obtained, the patient was started lamothyrigine therapy. While the dose was titrated in the treatment, treatment was stopped in the patient who developed SJS, and a new antiepileptic drug was started.

Conclusion: SJS/TEN is the same disease spectrum with different severity. They are classified according to the percentage of skin detachment area. The pathogenesis of SJS/TEN is still unclear and optimal treatment options are still controversial.

Keywords: Stevens Johnson Syndrome, toxic epidermal necrolysis, lamotirigine
ÖZ

Amaç: Stevens Johnson Sendromu ve Toksik Epidermal Nekroliz (SJS/TEN), hayatı tehdit edebilen, etiyolojisinde çeşitli faktörler olmakla birlikte genellikle ilaçlara karşı gelişen mukokutanöz cilt reaksiyonudur. Bu vaka sunumu ile anti-epileptik ilaç kullanımına bağlı gelişen SJS kısaca gözden geçirilecektir.

Olgu: 20 yaşında kadın hasta jeneralize tonik klonik nöbet ile acil serviste görüldü. Alınan ayrıntılı anamnez ve laboratuvar bulguları ile hastaya lamotirijin tedavisi başlandı. Tedavide doz titre edilirken SJS gelişen hastada tedavi kesilerek yeni anti-epileptik ilaç başlandı.

Sonuç: SJS/TEN farklı şiddette olan aynı hastalık spektrumudur. Cilt dekolmanı alanının yüzdesine göre sınıflanırlar. SJS/TEN'in patogenezi hala belirsizdir ve optimal tedavi seçenekleri tartışmalıdır. Etiyolojide sıkça ilaçlar sorumlu tutulmaktadır.

Anahtar Kelimeler: Stevens Johnson Sendromu, toksik epidermal nekroliz, lamotirijin 


\section{Introduction}

Stevens-Johnson syndrome and toxic epidermal necrolysis (SJS/TEN) are life-threatening diseases characterized by detachment of the epidermis and mucosal membranes. SJS/TEN are on the same spectrum of diseases with different severities. They are classified by the percentage of the skin detachment area. The pathogenesis of SJS/TEN is still unclear and optimal therapeutic options for SJS/TEN are controversial (1). This case is about a young girl who had lamotrigine induced Stevens-Johnson syndrome.

\section{Case Report}

The 20-year-old female patient had been diagnosed with idiopathic generalized epilepsy. Antiepileptic treatment of the patient who was under valproic acid treatment until three years ago had been discontinued in a controlled manner because she did not have seizures. However, the patient had applied to the emergency department with generalized tonic-clonic seizures lasting longer than five minutes, which occurred three times in the last two weeks. No pathological finding was detected in brain magnetic resonance imaging. We investigated possible causes of seizures. In electroencephalography, generalized theta form sharp slow-wave activity was observed at frequent intervals with a period of one second. Lamotrigine was started int his patients instead of valproic acid treatment due to potential side effects. While the treatment was increased by titration starting with the dose of $50 \mathrm{mg}$, the patient applied to the emergency department due to widespread rashes all over the body with a dose of $100 \mathrm{mg} 2 \times 1$. We learned that erythematous maculopapular eruptions started on the face and rapidly spread to the whole body (figure 1,2). The rash appeared approximately one week after the start of the drug when the dose was increased to $2 \times 100$ milligrams. The patient did not report any other symptoms accompanying the rashes. Her neurological examination was within normal limits and the rashes had covered about $10-30 \%$ of her body. With the current clinical appearance, SJS was diagnosed. Lamotrigine therapy was discontinued, and symptomatic therapy was innitiated. The rash started to regress the day after drug discontinuation. In symptomatic treatment, the patient was advised to drink plenty of fluids, nutritional support, and protection from possible infectious diseases. Due to epileptic seizures, her treatment was continued with levetiracetam.

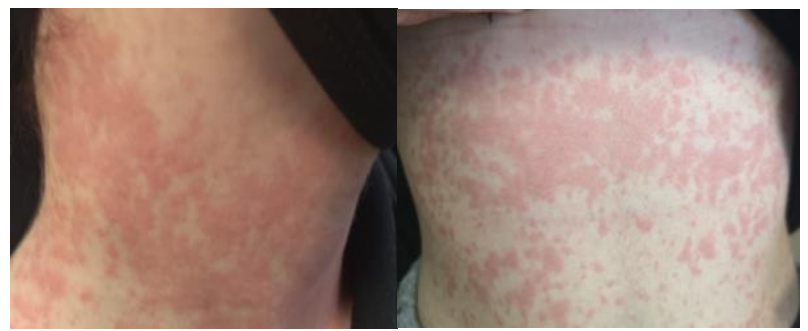

Figure 1\&2: erythematous maculopapular eruptions
Written informed consent was obtained from the patient for publication of this case report and any accompanying images.

\section{Discussion}

The main feature of SJS and TEN is severe damage to the skin and mucosal membranes, complicated by fever. In scientific literature, some studies reported incidence between 1-7 per million for SJS and 0.4 to 1.5 per million for TEN. In Europe and the United States, SJS is diagnosed when less than $10 \%$ of the body surface area is affected, SJS/TEN overlap when $10-30 \%$ is affected, and TEN when $30 \%$ or more is affected $(2,3)$. The most common cause of SJS is drug use. SJS / TEN is widely associated with anticonvulsants as well as antibiotics and NSAIDs. Due to hormonal factors, drug skin reactions related to anticonvulsants have been reported more in women than in men (4). Consistent with the literature, the rash in the female case had begun with the use of anticonvulsant drugs. Considering the physical examination findings and the area covered by the rash, a diagnosis of SJS was diagnosed. A study conducted in Japan in 2021, supporting previous studies had found that more cases of SIS/ TEN were observed with the use of carbamazepine and lamotrigine. In cases where antiepileptic has been started, care should be taken in terms of SJS/TEN for the first 90 days and patients should be warned about this (5). Various factors have been blamed for the development of Stevens-Johnson syndrome with medications. The triggering factor is that the drug or its metabolites act as haptens and bind to the keratinocyte surface and turn them into antigens. Drugspecific CD8(+) T cells activate caspase enzymes via Fas/FasL or perforin/granzyme B pathway, keratinocyte apoptosis is triggered, extensive epidermis damage occurs. In cases of SIS and TEN, the increase in proinflammatory cytokines such as TNF- $\alpha$, IL-6, IL-8, IL-13 also plays a role in the damage (6). These proinflammatory cytokine values were not examined in this patient.

Lamotrigine is a phenyltriazine derivative from the group of folic acid antagonists. Its main effect is voltage-dependent sodium channel blockade (7). Side effects are more common, especially when used with valproate. Valproic acid reduces the metabolism of lamotrigine, increasing the plasma half-life by up to 60 hours. Skin rash insidance increases when these two drugs are used together (8). Although it is necessary to be more careful in the combined use of these two drugs, SJS had been observed as a side effect in monotherapy, too as in our patient.

The severity of the disease and the quality of the health care provided determine the prognosis of the disease and the mortality rate. The mortality rate is less than $5 \%$ in SJS; It is $30 \%$ in TEN (9). The most important steps of treatment are early diagnosis and immediate discontinuation of suspicious drugs. Supportive therapy consists of fluid and electrolyte 
Side Effect of Lamotrigine; Stevens Johnson Syndrome

replacement, nutritional support, wound care, and prevention of sepsis, which is the most important cause of mortality (10). Rapid withdrawal of the culprit drug and intensive supportive care are the basis of treatment for SJS/TEN. The use of systemic corticosteroids and IVIG is still controversial. However, recently, there has been an increasing number of studies suggesting the efficacy of cyclosporine or TNF- $\alpha$ inhibitors (1). The first goal of treatment is to eliminate the factor that plays a role in the etiology. A decrease in rashes was observed in my patient with the discontinuation of lamotrigine therapy. By the end of about the sixth day, the rashe has completely disappeared.

\section{Conclusion}

SJS/TEN is a severe disease that has a high mortality rate. SJS/TEN is a drug side effect that should be kept in mind, especially in patients who have just started antiepileptic therapy. In addition to discontinuation of the etiological drug, neurology opinion should be obtained for the new antiepileptic drug to be administered.

Conflict of Interest: No conflict of interest was declared by the author.

Financial Disclosure: No financial disclosure was declared by the author.

Authors Contribution: This manuscript was written by one author.

Informed Consent Statement: Written informed consent was obtained from the patient for publication of this case report and any accompanying images. A copy of the written consent is available for review in this journal.

\section{References}

1. Hasegawa A, Abe R. Recent advances in managing and understanding Stevens-Johnson syndrome and toxic epidermal necrolysis. F1000Research. 2020;9:612.

2. Gerull R, Nelle M, Schaible T. Toxic epidermal necrolysis and Stevens-Johnson syndrome: a review. Crit Care Med 2011;39:1521-32.

3. Sunaga $Y$, Kurosawa $M$, Ochiai $H$, et al. The nationwide epidemiological survey of Stevens-Johnson syndrome and toxic epidermal necrolysis in Japan, 2016-2018. J Dermatol Sci. 2020;100:175-82.

4. S. Alvestad, S. Lydersen, E. Brodtkorb, Rash from antiepileptic drugs: influence by gender, age, and learning disability, Epilepsia. 2007; 48:1360-65.

5. Fukasawa T, Takahashi H, Takahashi K, et al. Risk of StevensJohnson syndrome and toxic epidermal necrolysis associated with anticonvulsants in a Japanese population: Matched casecontrol and cohort studies. Allergol Int. 2021;70(3):335-42.

6. Alpsoy E, Dicle Ö, Karakaş AA. Steven-Johnson Syndrome (SJS) and toxic epidermal necrolysis. Turkderm. 2010;44(4):180-6.
7. Stefan H, Feuerstein TJ. Novel anticonvulsant drugs. Pharmacol Ther. 2007;113(1):165-83.

8. Özcan $\mathrm{H}, \mathrm{Cenk} \mathrm{H}, \mathrm{Cumurcu} B$ Lamotrijin ve valproik asidin birlikte kullanımı sonucunda gelişen toksik epidermal nekroliz olgusu. Türkderm. 2015; 49: 169-72.

9. Ghislain PD, Roujeau JC: Treatment of severe drug reactions: Stevens-Johnson syndrome, toxic epidermal necrolysis, and hypersensitivity syndrome. Dermatol Online J. 2002;8:5.

10. Mockenhaupt M, Viboud C, Dunant A, et al. Stevens-Johnson syndrome and toxic epidermal necrolysis: assessment of medication risks with emphasis on recently marketed drugs. The EuroSCAR-study. J Invest Dermatol. 2008; 128:35-44. 